\title{
REQUIREMENTS FOR A SYSTEMS-BASED RESEARCH AND DEVELOPMENT MANAGEMENT PROCESS IN TRANSPORT INFRASTRUCTURE ENGINEERING
}

\author{
F.C. Rust \\ Built Environment \\ Council for Scientific and Industrial Research \\ Pretoria, South Africa \\ crust@csir.co.za
}

\begin{abstract}
The management of research and development (R\&D) in the transport infrastructure field is complex due to the multidisciplinary nature of the work. The literature shows that linear R\&D models that progress from idea through to consumer product are not suitable for the management of such multi-disciplinary projects. This study focuses on determining the key characteristics required for a systems-based approach to the management of R\&D projects. The information and data was compiled from literature reviews, interviews, and an e-mail survey with responses from 42 significant international R\&D programmes. The findings confirmed the need for a systems-based approach to R\&D management. The study formulated twelve principles or tenets for a new, systems-based approach.
\end{abstract}

\section{OPSOMMING}

Die bestuur van navorsing en ontwikkeling (N\&O) in die dissipline van vervoerinfrastruktuur is kompleks as gevolg van die multidissiplinêre aard van die werk. Die literatuur dui aan dat liniêre N\&O modelle wat van idee tot 'n gebruikersproduk vorder, nie toepasbaar is vir die bestuur van sulke multidissiplinêre projekte nie. Hierdie studie fokus op die bepaling van die sleutel eienskappe wat benodig word vir 'n stelsel-gebaseerde benadering tot die bestuur van N\&O projekte. Die inligting en data is versamel deur literatuur studies, onderhoude, en 'n e-pos vraelys met respondente van 42 internasionale N\&O programme. Die resultate toon aan dat daar ' $n$ behoefte is aan ' $n$ stelsel-benadering tot die bestuur van N\&O. Die studie het twaalf kernbeginsels gedefinieer vir so 'n stelsel-gebaseerde N\&O proses. 
A number of authors, including Porter [1] and Pistorius [2], have indicated that innovation in science, engineering and technology (SET) has a major impact on the social development and economic growth of a country. The effective management of research and development (R\&D) to optimise delivery and impact in the innovation process is therefore very important, especially in developing countries where resources are limited.

In some disciplines, innovation is focused more on 'soft' key solutions (such as software and new design methodologies used by government and professionals) rather than on consumer product development. An example of such a field is infrastructure engineering, where significant innovation focus is currently on design methods, construction methods, materials design, and software development, particularly related to the architectural and civil engineering disciplines, as previously reported [3,4]. Although innovation in the construction industry also focuses on the development of 'hard products' (albeit not consumer products such as construction equipment and new materials), the design and methodology aspects are paramount. These aspects can be viewed as both interdisciplinary and multidisciplinary, and provide a vital link in the innovation value chain between the natural sciences (or basic R\&D) and the effective socio-economic impact of infrastructure development.

Human resource development, as part of the R\&D process, is also very important in such disciplines. This is highlighted in the South African National R\&D Strategy [5], which states that R\&D investment is a significant contributor to human resource development. In a study of Japan (a successful developed country), Korea (a successful newly-industrialised country), and South Africa (a successful developing country), Lingela and Buys [6] found that Korea has nine times more researchers per capita than South Africa. This is indicative of the low levels of investment in R\&D in South Africa. Although the South African government has recently increased its target for R\&D expenditure to one per cent of GDP, this target has reportedly not been met [7]. In the infrastructure sector in particular, R\&D expenditure is as low as 0.3 per cent of industry turnover [8]. Grobbelaar and Buys [9] found that South Africa's capability to deliver R\&D outputs is under threat due to a high student-to-lecturer ratio, coupled with a lack of investment in the South African research core. These factors emphasise the complexity of managing R\&D, particularly in sectors where innovation is mainly in the form of new knowledge and methodology residing within key human resources.

Over the past seven years, a number of studies [3,4] have analysed the applicability of R\&D management models to the development of engineering methodology and design, by analysing the critical success and failure factors of six large R\&D programmes over a 20year period. The results showed that linear R\&D management models (which flow from idea through R\&D to product in the market) are particularly unsuitable to managing the development of key solutions in infrastructure engineering. Furthermore, fragmentation of the R\&D effort, particularly in terms of the number of projects and the project size, has had a very negative impact on some R\&D programmes. This negative effect of fragmentation has also been highlighted by a number of organisations $[10,11]$.

It was also found that existing R\&D management models are mostly linear in nature, and do not take into account the complex nature of the R\&D management process. This finding prompted work to determine the characteristics that are critical to an improved R\&D management process, with emphasis on R\&D programmes in the infrastructure domain. Thus this article describes the findings from a qualitative analysis of information available on R\&D management models and their characteristics, and the results of a survey among R\&D managers from 42 organisations worldwide to evaluate the importance of these characteristics and the current level of their usage. Twelve principles or tenets for the development of an R\&D management model suitable for the management of R\&D in 
infrastructure engineering were formulated, and recommendations were made for the development of such a system.

\section{THE CHALLENGE ASSOCIATED WITH LINEAR R\&D MANAGEMENT MODELS}

Complex systems and complexity theory have been researched extensively over the past 30 years. They have been applied in a number of disciplines, including management science, astronomy, chemistry, evolutionary biology, geology, and meteorology [12]. Such systems should not be confused with 'complicatedness' or being 'difficult to understand'. Cilliers [13] states: "There is no denying that the world we live in is complex, and that we have to confront this complexity if we are to survive, and, perhaps, even prosper". According to Cilliers, the traditional way to tackle complex challenges is to address them from a scientifically-determined, secure (and usually fixed) point of reference. Cilliers states that this is an avoidance of complexity. Solutions stemming from this approach will usually be linear and therefore not responsive to changes in needs and constraints. Such solutions are thus unlikely to be successful in addressing challenges such as the development of new methodologies, soft systems, human capital development, and management processes.

Cilliers also analysed the nature of organisations, and showed that they are inherently complex systems. An analysis showed that the research process exhibits many of the characteristics of a complex system, as indicated in Table A1 in Appendix A.

Wagner-Luptacik et al. [14] also indicated that the innovation process is a dynamic and complex system, and that simplistic, linear models fail to predict the behaviour of the system accurately. In addition, Dekkers [15], who conducted a survey among 68 companies and did five in-depth case studies, found that industrial practices in innovation management still rely on incremental innovation, depend on hierarchical managerial practices, and have an inward departmental orientation, and therefore do not take cognisance of the complexity of the process.

A South African study [16] highlighted the challenges associated with using linear models for R\&D management in the infrastructure sector. The authors indicated that linear, forward thinking, as opposed to a systems approach, creates challenges. These include: fragmentation of the R\&D effort; small projects with diminished output; lack of mentoring of young researchers due to the smaller projects; and, consequently, non-performance of R\&D programmes. This fragmentation of the South African infrastructure and transport sector R\&D programme, exacerbated by lowest price tendering procedures, has been very detrimental. It created a situation where, on average, each researcher was conducting three small projects, with a consequent lack of focus and mentoring opportunities. The study further showed that this led to significantly reduced output from the R\&D programme.

Dimitratos and Plakoyiannaki [17], in a study of organisational culture and entrepreneurship, also found that the lack of a systems approach results in fragmentation and its associated negative outcome. Nature [10] reported that Germany had also realised that a systems approach is required to counter fragmentation. Similar intentions have been expressed by the European Commission [11].

Rust et al. [16] concluded that there is a need to develop systems-based R\&D management approaches that take cognisance of the complex nature of the R\&D process, particularly in multi-disciplinary research that focuses on engineering methods and techniques as outputs.

\section{IMPORTANT CHARACTERISTICS OF R\&D MANAGEMENT IDENTIFIED FROM THE LITERATURE}

A literature review [3] identified a number of elements that are important in developing an R\&D management process. Some of these are discussed briefly below. 


\subsection{A holistic, systems approach}

According to Flood and Jackson [18], systems thinking emerged in the 1940s as a response to the failure of mechanistic thinking to explain biological phenomena. In particular, it is necessary to view organisms as whole entities or systems whose identity and integrity have to be respected. Organisms were seen as having 'emergent' properties that were unique to themselves and that could not be derived from their parts. They were also seen as 'open' rather than 'closed' to their environment. A system thus comprises elements that are linked to one another through a series of relationships. If a group of elements are richly interactive, a boundary can be drawn around them separating them from their environment. A system also has inputs and outputs with feedback loops that influence the operation of the system, and therefore the whole is usually more than the sum of the parts.

Roussel [19] indicated that a holistic approach to R\&D management, involving all the stages of the development of a product (i.e. research, development, engineering design, and manufacturing), rather than a sequential approach, should be followed. 'Third generation R\&D' is defined by Roussel as a process "seeking to create across business units, across divisions, and across the corporation a strategically balanced portfolio of R\&D formulated jointly in a spirit of partnership between general managers and R\&D managers".

Chesbrough [20] and West and Gallagher [21] discuss the concept of 'open innovation', and contend that it is a new paradigm of cooperation in R\&D and innovation that can provide sustainable growth in the future. The process is defined as the use of inflows and outflows of knowledge to and from a company to accelerate internal innovation, and to expand markets for the external use of innovation. Chesborough describes open innovation's holistic approach to innovation management as “...systematically encouraging and exploring a wide range of internal and external sources for innovation opportunities, consciously integrating that exploration with firm capabilities and resources, and broadly exploiting those opportunities through multiple channels".

\subsection{A multidisciplinary approach that integrates different competencies}

Pretorius and de Wet [22] discuss the importance of the integration of different technologies to optimise productivity. Gann [23] stresses that innovation in longer-term capital investment projects, such as transport infrastructure, is different in nature from that of the manufacturing sector. Capital projects are usually demand-driven, and consist of project-based activities rather than batch production or mass manufacturing systems that produce goods for the consumer market. Firms in engineering and construction compete in dynamic environments where they need to manage technological innovation and uncertainty across organisational boundaries with networks of interdependent suppliers, customers, and regulatory bodies. The knowledge of providing capital infrastructure is distributed throughout these networks, and therefore innovation can only take place in an environment where effective communication can take place. Phaal et al. [24] indicated that, in technology road mapping, integration needs to take place between the competencies of technical development and commercial activity.

\subsection{Core competencies and platforms}

Prahalad and Hamel [25] define a core competency as the collective learning in the organisation, relating especially to how to co-ordinate diverse production skills and integrate multiple streams of technologies across organisational boundaries. Organisational growth is one of the main factors ensuring long-term viability in companies. Prahalad and Hamel stress the fact that the successful corporation will have to rethink its business strategy to structure itself around core competencies rather than business for growth.

Meyer and Utterback [26] discuss product platforms that are the result of the application of a company's core capabilities. According to Jolly and Nasiriyar [27], a technology platform has a distinctive, inherent set of technologies that provide competitive advantage. Shapiro [28] also discusses the concept of a platform to understand the level of innovation and renewal in a company. Viewing platforms as a foundation on which to build new products 
(such as those used by the company $3 \mathrm{M}$ ), and calculating company revenue derived from new platforms, is important to understanding the level of product renewal in a company.

\subsection{Invention and creativity}

Innovation is defined by Roberts [29] as follows:

"Innovation is composed of two parts: (1) the generation of an idea or invention, and (2) the conversion of that invention into a business or other useful application. Or in simple terms:

Innovation = Invention + Exploitation"

Invention is the process of idea generation and making ideas work. Essential to this process is the element of creativity. The exploitation process includes the stages of commercialisation and technology transfer.

\subsection{Fragmentation of research activity}

In a case study of six South African transport research programmes, Rust et al. [16] indicated that fragmentation of a research programme into ever-decreasingly small projects had a very negative effect on the effectiveness of the programme. It led to loss of focus by researchers, low levels of mentoring of junior staff by senior researchers, less effective peer review of results, and less effective innovation. This was confirmed by Dimitratos and Plakoyiannaki [17], who found that the lack of a holistic, systemic approach leads to fragmentation, with the associated negative results.

\subsection{Effectiveness measurement of R\&D}

Innovation outcomes and results are inextricably linked to the quality of the R\&D management activities that form a part of the innovation chain. The measurement of R\&D outcomes and results is complex, and the work conducted to date, such as that reported in the OSLO manual [30], focuses on innovation related to the development of hard products in the private business sector. The measurement of research performance is complex, and indicators can vary depending on the type of organisation that conducts the research, the source of funding, or the sector in which the research organisation operates. Germeraad [31] also described some of the typical metrics and indicators - mainly in the manufacturing sector (hard products) - used to value R\&D activity. However, most of the metrics are only aimed at return on investment, cost avoidance, and product quality. Sohn et al. [32] stress the importance of internal management processes, external review, and the quality of the analysis of the R\&D programme information in companies that conduct R\&D to enhance the performance of the R\&D programme.

\subsection{Stakeholders and technology transfer}

Technology transfer is an important part of the innovation chain. There are a number of models and theories on technology transfer and diffusion. The well-known S-curve is often used to describe the state of a technology's performance and its rate of diffusion in the market place [33]. Nieto et al. [34] examined the theoretical foundation of the S-curve model and discuss problems experienced with its implementation, particularly the measurement of performance indicators. Barbolla and Corredera [35] found that satisfactory technology transfer is a combination of factors that include real interest in the stakeholder organisations in both project development and in its final result, as well as high motivation and a good command of the necessary knowledge to undertake the project.

\subsection{Internal and external communication}

Allen et al. [36] discussed the importance of social networks in the development, exchange, and dissemination of knowledge within the R\&D function in a company. A formal analysis of such networks allows management to foster the network, thus improving its performance. Allen et al. also stated that the structure of an R\&D organisation should be closely related to the desired communication process within the organisation, whether internal technical communication or external commercial communication. 
The literature review has indicated a number of important aspects that should be considered in determining the critical characteristics of an effective R\&D management process.

\section{OBJECTIVES AND RESEARCH METHODOLOGY}

As indicated above, a significant portion of research in the infrastructure and transport sectors is focused on engineering methodology intended for use by engineering professionals, rather than on developing hard products for consumers' markets. The main purpose of the study was to develop a systems-based model for R\&D management in this sector, taking its particular characteristics into account. This article discusses the process and the determination of the characteristics that would be important to support such an alternative model.

The approach followed $[3,4]$ was a mixed research model employing both qualitative and quantitative analysis of information and data. Qualitative analyses of existing information and innovation management models, case studies [3], and a survey were used to develop twelve tenets to support the development of a conceptual, alternative R\&D management model.

The data and information for this study were collected from:

- $\quad$ interviews and workshops with professionals in the transport infrastructure sector;

- analyses of six historical research programmes and three significant long-term research projects using a case study approach [3]; and

- a survey to assess the level of use of specific elements of R\&D management processes among research managers, and of how important they consider these elements to be.

This qualitative research led to the definition of a number of potentially critical characteristics required for a relevant and successful R\&D management model.

The survey was used to determine the extent of use of these characteristics of the R\&D management process, and how significant they are considered to be by survey respondents. The extent to which R\&D management tools are used was also evaluated. The following characteristics were included in the survey:

- $\quad$ the linking of the R\&D programme and projects to an overall strategic plan;

- $\quad$ the differentiation in management processes between longer-term basic R\&D projects and shorter-term development projects;

- the use of portfolio management tools to balance the research project portfolio;

- the use of formal technology transfer projects to ensure the implementation of research results;

- the formal assessment of the impact (effectiveness) of R\&D programmes and projects;

- the use of integrated, systems-based approaches in R\&D management, including feedback loops to ensure team learning;

- the use of a formal investment decision process to allocate funding to projects;

- the use of formal planning of human resource development; and

- $\quad$ the use of formal project management processes.

The extent to which the following tools were used was also evaluated:

- $\quad$ scenario planning;

- technology foresight studies;

- $\quad$ stakeholder needs analysis;

- $\quad$ technology road mapping;

- technology trees; and 
The survey used a five-point Lickert scale, and the results were converted to numerical data to allow for statistical analysis using the software SPSS $\vee 16$.

\section{RESULTS OF THE SURVEY}

\subsection{Target group}

Significant efforts were made to ensure that R\&D organisations in the infrastructure and transport fields participated. Although the final list of 126 organisations cannot be guaranteed to be the full population, it is an extensive list [3]. No sampling was done of the target group, and the survey was sent to the whole group. The 45 voluntary respondents represent 42 independent R\&D programmes (in three cases, the researchers in a programme and their managers responded).

The survey was sent to R\&D managers in a number of local and international organisations operating across a variety of research fields, but concentrating mainly on the transport, infrastructure, road engineering, and construction fields.

\subsection{Respondent analysis}

The profile of the respondents is depicted in Figure 1 below.

- 54 per cent of the respondents were from South Africa, and the remainder from international organisations;

- 63 per cent of the respondents were R\&D managers, and the remainder general managers or researchers;

- 40 per cent of the respondents were from educational institutions, 31 per cent from state-owned enterprises (government research laboratories), and only one (3 per cent) from the private sector; and

- 63 per cent of the respondents were from infrastructure-related R\&D programmes.

\subsection{Annual budget and number of researchers}

The average annual budget, the number of researchers, and the number of projects per R\&D programme are shown in Figure 2 . The figure indicates that there was a spread of budget sizes and research team sizes. The survey included a number of large R\&D programmes (in excess of $\$ 10$ million per annum and more than 100 researchers).

\subsection{Exploratory analysis of the data}

\subsubsection{Comparison of basic statistics}

In order to analyse the data statistically, the five-point Likert scale was converted into a numerical scale, with ' 1 ' being the lowest score. The data obtained from the survey was processed using SPSS version 16.0; the results are shown in Table A2 in Appendix A. Apart from the usual statistical information, the table also shows the 'gap in application' by subtracting the 'extent of use' score from the 'importance' score, as described above.

\section{Data distribution}

The skewness values for the data shown in Table A2 in Appendix A are generally low (except for the use of R\&D management tools), indicating that the data set is roughly normally (or at least symmetrically) distributed. However, both the mean and the median values are reported and were used in the summary, particularly because the sample is relatively small.

\section{R\&D management characteristics}

The data in Table A2 in Appendix A indicates that the following characteristics are used most often: 


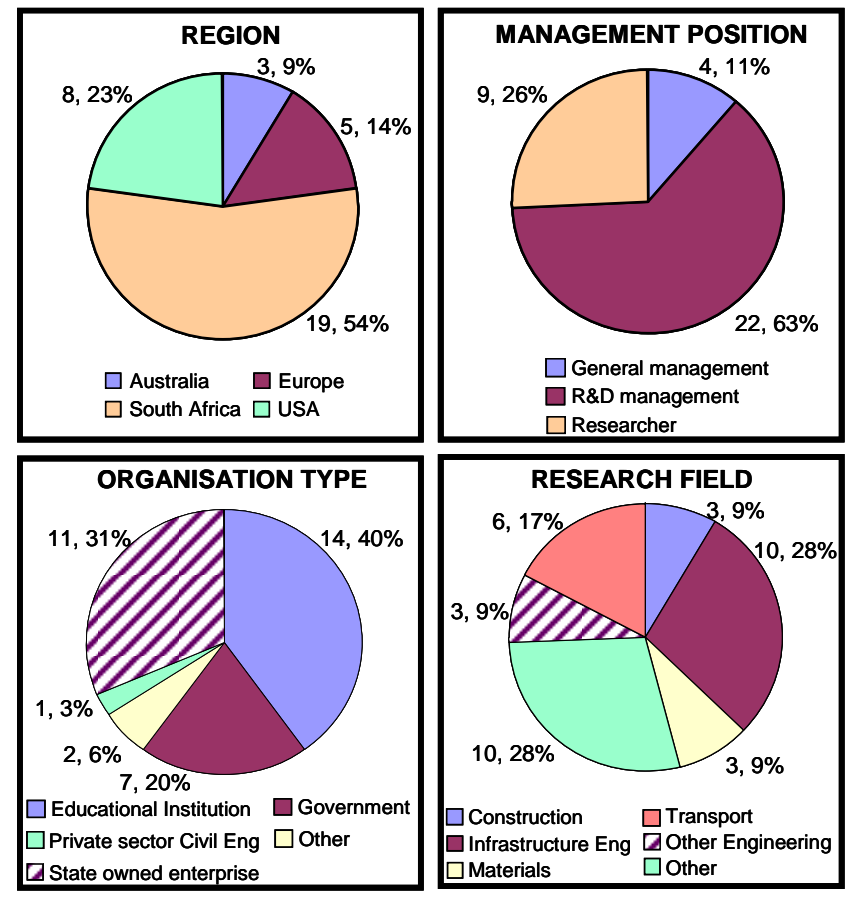

Figure 1: Profile of survey respondents
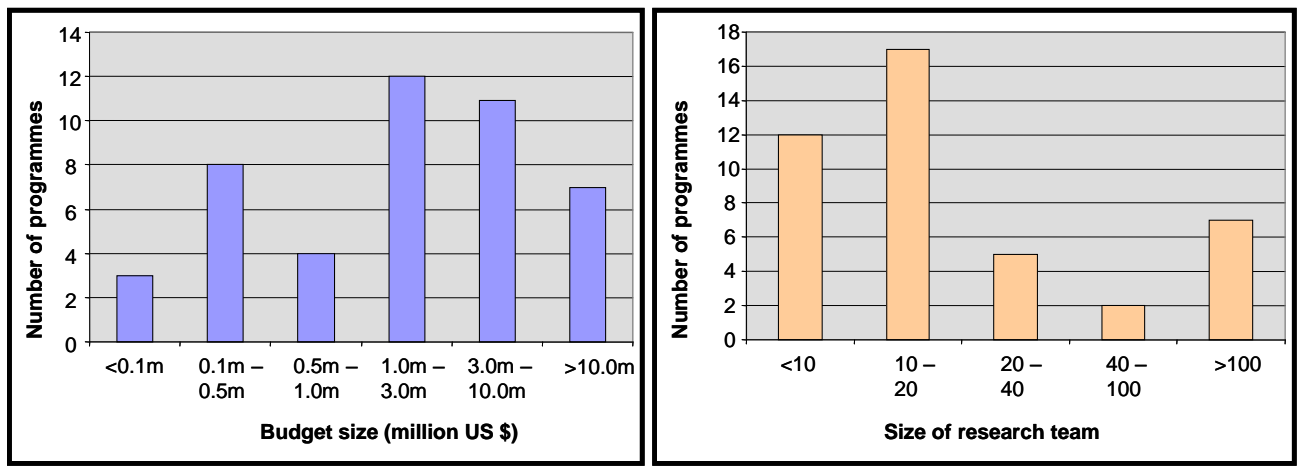

Figure 2: Histograms of budget size and size of the research team

- $\quad$ linkage of R\&D programme and projects to a strategic plan;

- management of longer-term basic R\&D projects vs shorter-term development projects;

- $\quad$ the use of a formal investment decision process to allocate funding to projects;

- $\quad$ the use of formal planning of human resources development; and

- $\quad$ the use of formal project management processes.

With the exception of portfolio management, all the characteristics were rated 'relatively important'. The gap between 'importance' and 'extent of use' was highest for:

- $\quad$ the use of portfolio management;

- formal technology transfer projects;

- $\quad$ the formal assessment of impact; and

- $\quad$ the use of integrated, system-based approaches in R\&D management.

This indicates that there is a potential need for new knowledge, methods, tools, and a conceptual model to address these areas. 
Use of R\&D management tools

The use of technology management tools is generally rated 'low', except for 'needs determination processes'.

\subsubsection{Basic statistics per region, position, and organisation type}

The mean values and standard deviation of the responses were analysed based on the following variables:

- $\quad$ region (Europe, South Africa, USA, Australia);

- $\quad$ career position of respondent (general manager, R\&D manager, researcher);

- $\quad$ organisation type (government, state-owned enterprise, university, private, other); and

- field of research (transport, materials, construction, infrastructure engineering, other engineering, other).

For first-order comparison, the total score of all the questions answered by each respondent for each of the three categories ('extent of use', 'importance', 'use of tools') was calculated. This allows for the assessment of bias between respondents based on, for example, their origin or career position. The mean values, median values, and standard deviation per variable and grouping of these total scores are shown in Figure 3 below.

From Figure 3 the following can be derived:

- Europe has a lower total average score for extent of use, importance, and use of tools; the other regions are very similar to one another;

- general managers and R\&D managers scored higher than researchers (probably because they are more involved in the management of R\&D than researchers are);

- universities scored lower than government and state-owned enterprises; and

- in the research field, the scores were marginally higher for transport, infrastructure engineering, and other - but there was no strong relationship between research field and total score. This may indicate that the results are applicable to research fields other than transport and infrastructure.
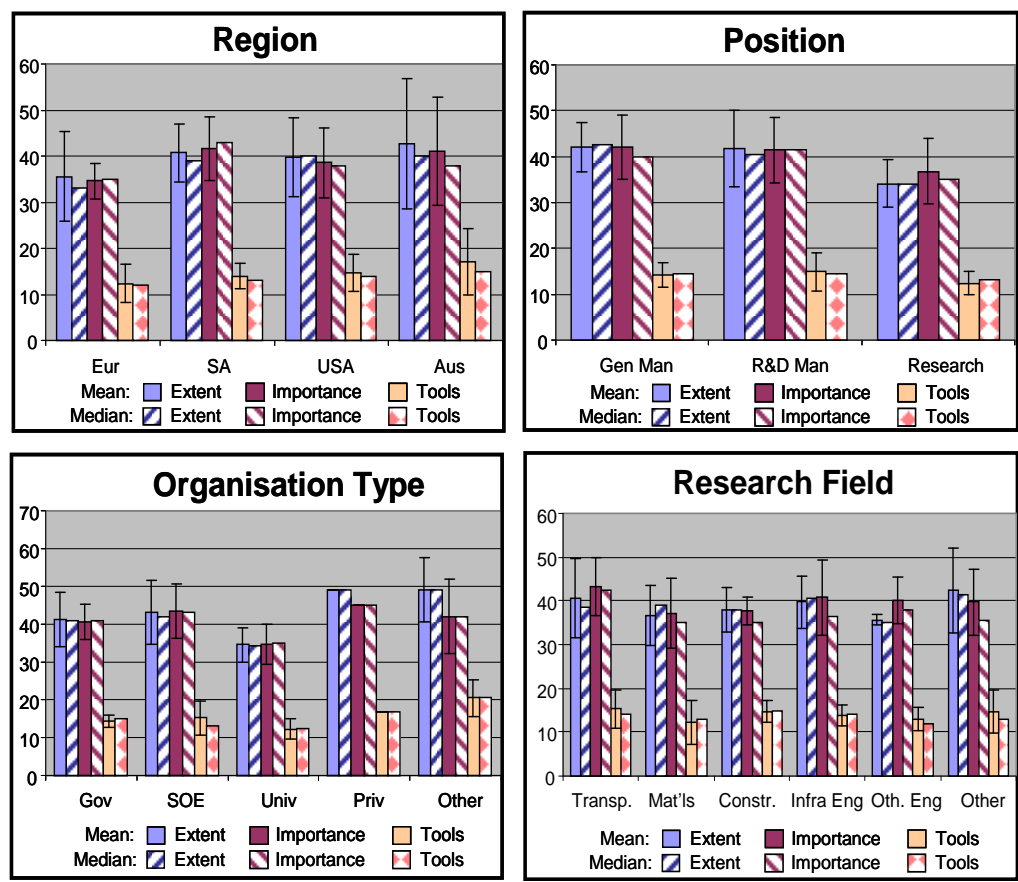

Figure 3: Mean score, median score, and standard deviation per grouping 
A between-groups analysis of variance (ANOVA) was conducted to explore the influence of the four independent grouping variables on the total score for extent of use. The 'organisation type' had a statistically-significant influence on the total score for 'extent of use' $(F=6.67, p=0.006)$, with 'management position' $(F=3.53, p=0.06)$ being marginally significant. There was no significant influence from 'region' or 'research field'. This confirms the visual observations from Figure 3 above.

\subsection{Principal component analysis}

Factor analysis, or principal component analysis (PCA), was used to investigate the interrelationships of the variables and to assess the potential of reducing the number of characteristics from the original nine to a lower number [3]. The 'extent of use' and 'importance' scores were analysed separately.

The PCA indicated three components with eigenvalues of more than one in the case of the 'extent of use' group of variables, and four components in the case of the 'importance' group of variables. The matrices for the first three components for 'extent of use' and the first four components for 'importance' are shown in Table 1.

The weights or loadings of variables on the components of the 'extent of use' data do not seem to lead to any practical or logical interpretation, and all these variables should be retained as individual variables for further analysis.

Table 1: Component matrices for 'extent of use' and 'importance'

\begin{tabular}{|c|c|c|c|c|c|c|c|c|}
\hline \multicolumn{4}{|c|}{ Component matrix: Extent of use } & \multicolumn{5}{|c|}{ Component matrix: Importance } \\
\hline & \multicolumn{3}{|c|}{ Component } & & \multicolumn{4}{|c|}{ Component } \\
\hline & 1 & 2 & 3 & & 1 & 2 & 3 & 4 \\
\hline TechTransE & 0.805 & & -0.381 & Systeml & 0.756 & & & \\
\hline SystemE & 0.689 & & -0.355 & ProjManl & 0.719 & & & -0.417 \\
\hline PortfolE & 0.593 & & 0.361 & Impactl & 0.71 & & & \\
\hline StratPlanE & 0.562 & 0.368 & & InvesDecl & 0.655 & -0.309 & -0.344 & \\
\hline ImpactE & 0.513 & & & LongShortl & 0.614 & -0.501 & & 0.365 \\
\hline LongShortE & & 0.76 & & Portfoll & 0.601 & & -0.455 & 0.416 \\
\hline ProjManE & 0.355 & 0.704 & -0.406 & HumResl & & 0.84 & & \\
\hline InvesDecE & 0.508 & -0.578 & 0.369 & StratPlanl & & & 0.824 & \\
\hline HumResE & & & 0.847 & TechTransl & 0.454 & & & -0.6 \\
\hline
\end{tabular}

Inspection of the components for the 'importance' data reveals that the variables, over the life cycle of a research programme (planning, projects, technology transfer, impact assessment), can be grouped together into four components that make some logical sense:

- Component 1: Systems approach, which includes a number of the variables that describe the use of a holistic systems approach in R\&D management;

- Component 2: Human resource development, which is influenced by the investment decision (of which funding for HR development is a part), and by long-term versus short-term projects (because longer-term projects allow room for HR development);

- Component 3: Strategic planning, which includes some elements of the investment decision and portfolio management; and

- Component 4: Technology transfer, which includes some elements of project management, long-term vs short-term projects (because technology transfer projects are shorter-term projects), and portfolio management.

This analysis indicates that these four aspects of R\&D management can be seen as potential groupings within the 'importance' data. It can therefore be postulated that the respondents indicated that these four characteristics are important for an R\&D management process. 

PROCESS

The results from the literature review, the analysis of the case studies $[3,4]$, and the survey discussed above were used to define a number of characteristics or tenets that should be considered in the development of an R\&D management process particularly, but not exclusively, in the infrastructure domain. These are described briefly below.

Tenet 1: A holistic approach should be integral to the process

As indicated from the literature review, the model should take account of the broader environment within which the programme takes place, which includes the needs of stakeholders and communities. Interaction with all role players is essential, and their R\&D efforts should be co-ordinated. The process should take cognisance of the full innovation chain, including the eventual impact of the programme. In this process, the end objective (uptake and impact of the result) should be visualised and should define the nature of the R\&D process.

Tenet 2: The process should be based on a systems approach

As indicated from both the literature review and the survey, the model should take cognisance of the principles of systems thinking and complexity theory, with a specific emphasis on:

- $\quad$ non-linear thinking to address the development of new engineering methodology and knowledge, as opposed to the development of hard products for the consumer market;

- $\quad$ the interaction between the elements of the system and their interdependency;

- $\quad$ the interaction of the system with the system's environment;

- feedback loops that allow control, self-reference, and self-organisation;

- $\quad$ circular causality, which means that the system can impact on itself;

- $\quad$ the fact that small changes can cause large effects elsewhere in the system; and

- $\quad$ some degree of informed reduction to deal with the breadth of the problem.

Tenet 3: Integration of elements or levels of the process should be used to enhance the value and quality of the outcome from the research process

The literature review indicated that a number of disciplines need to be integrated to address the complexity of the process to develop solutions for the road infrastructure industry. These solutions should be implementable, usable by stakeholders, and acceptable to communities. The integration of basic pockets of expertise to deliver higher-order key solutions that will provide long-term impact should be emphasised.

Tenet 4: The manpower pool should be central to the process

Both the literature and the survey indicated that the effectiveness of any R\&D programme depends to a large degree on the quality of the researchers and practitioners involved in the process, particularly where innovation in technical organisations is concerned. The quality of the manpower pool should therefore be integral to the process, and the research programme should be linked to future manpower development.

Tenet 5: Strategic planning must be a core element of the process

The survey and case studies indicated that the strategic planning and vision for both the road industry and the research organisation must form an integral part of the process, and must allow for a body (e.g. a steering committee) to provide strategic direction to the programme.

Tenet 6: The research and development programme must be balanced

Balance implies that there should be a strategic view of the balance between solving shortterm problems and building new technology and knowledge platforms in the long term. The survey and the literature indicated that there should be a balance between 'market pull' and 'technology push'. 
Tenet 7: Core competencies and platforms should be integral to the model

The literature review indicated that the concept of core competencies and technology platforms should form an integral part of the model to ensure that long-term R\&D capability is developed, that critical mass in terms of human resources is developed, and that stakeholder needs are addressed effectively.

Tenet 8: The process must stimulate creativity and invention

The literature review showed the importance of allowing enough room for researchers to be inventive, to ensure that new knowledge generation is effective.

Tenet 9: The process should counter the effects of fragmentation

The literature review highlighted that the process should stimulate the formulation of larger, multi-year, multidisciplinary projects to ensure increased return of value for the investment made.

Tenet 10: The process should assess the effectiveness of the R\&D process

Both the literature review and the survey showed that the model must allow for the effectiveness and the eventual impact of the R\&D programme to be assessed.

Tenet 11: Stakeholder interaction and technology transfer are essential

The literature emphasised how essential it was that stakeholders and communities be involved in the planning and the technology transfer stages of the process, to ensure that stakeholder needs are addressed and that implementation is facilitated.

Tenet 12: The process should allow effective internal and external communication, including the motivation for stable long-term funding

According to the literature review, it is important that the process should allow researchers to communicate effectively about research activities across the boundaries of a number of disciplines. The programme of work should also be linked to stakeholder needs to ensure that stakeholders understand the need for, and the objectives of, the R\&D programme.

\section{CONCLUDING REMARKS AND FUTURE WORK}

The qualitative and quantitative research conducted in this study focused on:

- $\quad$ interviews and workshops with professionals in the transport infrastructure sector;

- analyses of six historical research programmes and three significant long-term research projects, using a case study approach; and

- a survey to assess the level of use of specific elements of R\&D management processes among research managers, and how important they consider these elements to be.

This work has indicated that there is a need for a non-linear approach to research management. This is particularly true in disciplines and research fields where the outputs are in the form of new knowledge, methodology, and design processes ('softer' research outputs) as opposed to consumer products.

The work has identified twelve tenets that can be used to develop an alternative research model and tools to manage research in the infrastructure and transport sector. The survey was conducted among researchers and managers from a number of disciplines. The analysis of the data did not show distinct differences between respondents from a range of disciplines. Thus it can be postulated that the findings are applicable not only to the transport sector.

This work has been used as input into a process for the development of a holistic, systemsbased model and tools for the management of such R\&D processes, which will be discussed in a future publication. 


\section{ACKNOWLEDGEMENTS}

This paper is published with the permission of the Executive Director of the CSIR Built Environment Unit.

\section{REFERENCES}

[1] Porter, M.E. 1990. The competitive advantage of nations. Harvard Business Review, March April, 2(3), pp. 73-93.

[2] Pistorius, C. 1996. Technology as the engine of growth. Research for a Competitive Industry, Scientech '96, Annual magazine of the Foundation for Research Development, p 2.

[3] Rust, F.C. 2009. A systems approach to managing R\&D in the road infrastructure sector in South Africa. PhD Thesis, University of Witwatersrand, Johannesburg.

[4] Rust, F.C. 2010. Critical requirements for a systems-based R\&D management process. CSIR Biennial Conference: 'Science real and relevant', Pretoria, August 2010.

[5] South Africa's National Research and Development Strategy. 2002. South African Department of Science and Technology, Pretoria, South Africa, August 2002.

[6] Lingela, V. \& Buys, A. 2007. An innovation management framework to improve national competitiveness in developing countries. Proceedings of the 16th International Association of Management of Technology Conference (IAMOT), Florida, USA, pp 1572-1593.

[7] National survey of research \& experimental development (2009/10 Fiscal Year): High-level key results. 2013. Human Science Research Council, Pretoria, South Africa.

[8] Rust, F.C., van Wyk, L., Ittmann, H. \& Kistan, K. 2008. The role of R\&D in transport infrastructure in South Africa. Proceedings of the South African Annual Transport Conference, Pretoria.

[9] Grobbelaar, S. \& Buys, A. 2006. Research and development in the South African system of innovation - Application of a system dynamics model to the higher education system. Proceedings of the 15th International Association of Management of Technology Conference (IAMOT), China.

[10] German council urges collaboration to boost science output. Brief article in Nature 406, p 116.

[11] European Commission. 2003. Website of the European Commission, http:// ec.europa.eu/research/press/2003/pr1112en.html, accessed in January 2014.

[12] Rosenhead, J. \& Mingers, J. 2001. Rational analysis for a problematic world revisited: Problem structuring methods for complexity, uncertainty and conflict, 2nd ed. Wiley, Hoboken.

[13] Cilliers, P. 1998. Complexity and postmodernism. London: Routledge Publishers.

[14] Wagner-Luptacik, P., Heller-Schuh, B \& Leitner, K.H. 2006. The firm as innovation system: Applying complexity principles to drive new product development. Proceedings of the 15th International Association of Management of Technology Conference (IAMOT), China.

[15] Dekkers, R. 2007. Did the paradigm shift in innovation management occur? Proceedings of the 16th International Association of Management of Technology Conference (IAMOT), pp 1749-1768.

[16] Rust, F.C, McCutcheon, R.T. \& Coetzee, L. 2008. Transport research: Quo vadis? Proceedings of the South African Annual Transport Conference, Pretoria.

[17] Dimitratos, P. \& Plakoyiannaki, E. 2003. Theoretical foundations of an International entrepreneurial culture. Journal of International Entrepreneurship (1), pp 187-215.

[18] Flood, R.L. \& Jackson, M.C. 1991. Creative problem solving. John Wiley and Sons: UK, pp 5-6.

[19] Roussel, P.A., Saad, K.N. \& Erickson, T.J. 1991. Third generation R\&D. Harvard Business School Press, Boston, Massachusetts, USA.

[20] Chesbrough, H.W. 2003. Open Innovation: The new imperative for creating and profiting from technology, Harvard Business School Press: Boston, USA.

[21] West, J. \& Gallagher, S. 2006. Challenges of open innovation: The paradox of firm investment in open-source software. R\&D Management 36(3), pp 319-331.

[22] Pretorius, M.W. \& de Wet, G. 2000. A model for the assessment of new technology for the manufacturing enterprise. Technovation 20, Elsevier Science Ltd, pp 3-10.

[23] Gann, D. 1997. Technology policy: An international comparison of innovation in major capital projects. Paper presented at the 1st International Conference on Technology Policy and Innovation, Macau.

[24] Phaal, R., Farrukh, C.J.P. \& Probert, D.R. 2001. Characterisation of technology roadmaps: Purpose and format. Proceedings of Portland International Conference on Management of Engineering and Technology (PICMET) (1), pp 367-374.

[25] Prahalad, C.K \& Hamel, G. 1990. The core competence of the corporation. Harvard Business Review (3), pp 79-91.

[26] Meyer, M.H. \& Utterback, J.M. 1993. The product family and the dynamics of core capability. Sloan Management Review (34), pp 29-47. 
[27] Jolly, D.R. \& Nasiriyar, M. 2007. Technology platform exploitation: Definition and research boundaries. Proceedings of the 16th International Association of Management of Technology Conference (IAMOT), Florida, USA, pp 1786-1806.

[28] Shapiro, A.R. 2006. Measuring innovation: Beyond revenue from new products. ResearchTechnology Management 49(6), pp 42-51.

[29] Roberts, E.B. 1988. Managing invention and innovation. Research Technology Management, 31(1), pp 11-29.

[30] OECD. 2005. OSLO Manual: Guidelines for interpreting and collecting innovation data. 3rd ed., Organisation for Economic Co operation and Development.

[31] Germeraad, P. 2003. Measuring R\&D in 2003. Research-Technology Management 46(6), pp 47-56.

[32] Sohn, S.Y., Yong Gyn, J. \& Hong Kyu, H. 2007. Structural equation model for the evaluation of national funding on R\&D project of SMEs in consideration with MBNQA criteria. Evaluation and Program Planning 30(1), pp 10-20.

[33] Betz, F. 1996. Forecasting and planning technology. In: Gaynor, GH (ed.), Handbook of technology management. McGraw-Hill: New York, USA, p 12.2.

[34] Nieto, M., Lopez, F. \& Cruz, F. 1998. Performance analysis of technology using the S-curve model: The case of digital signal processing (DSP) technologies. Technovation 18(6/7), p 439.

[35] Barbolla, A.M.B. \& Corredera, J.R.C. 2006. Factors for success in university-industry research contracts. Proceedings of the Second European Conference on Management of Technology: Doctoral papers, Birmingham, UK, pp 1-8.

[36] Allen, J., James, A.D. \& Gamlen, P. 2007. Formal versus informal knowledge networks in R\&D: A case study using social network analysis. R\&D Management 37(3), pp 179-196. 


\section{APPENDIX A}

Table A1: Characteristics of complex organisations and similarity with the research process - after Rust [3]

\begin{tabular}{|c|c|}
\hline Organisation (after Cilliers [13]) & Author's comments on the R\&D process \\
\hline $\begin{array}{l}\text { The behaviour and nature of a complex organisation are } \\
\text { determined by the interaction between its members, and } \\
\text { relationships between parties are therefore critical. }\end{array}$ & $\begin{array}{l}\text { A number of players interact continually at the individual level (researchers, practitioners, stakeholders, } \\
\text { and funders), as well as at the organisational level (research organisations, universities, funding bodies, } \\
\text { professional institutions, government departments, private sector companies, etc.). }\end{array}$ \\
\hline $\begin{array}{l}\text { Complex organisations are open systems, and therefore large } \\
\text { quantities of information flow through them, meaning that a } \\
\text { stable state is not desirable. }\end{array}$ & $\begin{array}{l}\text { The R\&D process needs to assimilate information from outside, and continually to transfer knowledge and } \\
\text { technology back to users and stakeholders. }\end{array}$ \\
\hline $\begin{array}{l}\text { The boundaries in an organisation are not clearly defined, and } \\
\text { there is usually some overlap or co-operation between } \\
\text { departments. }\end{array}$ & $\begin{array}{l}\text { The boundary around the R\&D process can vary depending on the number of participants. Often there are } \\
\text { strategic partnerships and similar research that takes place in more than one organisation. }\end{array}$ \\
\hline $\begin{array}{l}\text { Organisations have to interact with their environment and other } \\
\text { organisations. }\end{array}$ & $\begin{array}{l}\text { The R\&D process incorporates a number of organisations that interact with each other and with users and } \\
\text { stakeholders in a national system of innovation. }\end{array}$ \\
\hline $\begin{array}{l}\text { The context and the history of an organisation determine its } \\
\text { nature, and this history is distributed through the elements and } \\
\text { interactions. }\end{array}$ & $\begin{array}{l}\text { A study of transport research in South Africa [3] has shown that historic trends had a significant impact on } \\
\text { the performance of the programme. }\end{array}$ \\
\hline $\begin{array}{l}\text { Unpredictable behaviour and characteristics may emerge from an } \\
\text { organization; they may not be desirable, but are not, by } \\
\text { definition, an indication of malfunctioning (emergent properties). }\end{array}$ & $\begin{array}{l}\text { R\&D is inherently unpredictable in terms of outcome; and the fragmentation of the programme was an } \\
\text { unwanted emerging property in terms of the operational process in the historic transport research } \\
\text { programme [3]. }\end{array}$ \\
\hline $\begin{array}{l}\text { Due to the non-linearity of interactions between elements, small } \\
\text { causes can have large effects; thus the magnitude of the effect is } \\
\text { not only determined by the size of the cause, but also by the } \\
\text { context and history of the system. }\end{array}$ & $\begin{array}{l}\text { The analysis of several South African transport R\&D programmes [3] showed that the implementation of a } \\
\text { tendering process (small change) had a very large detrimental effect (fragmentation and ultimate collapse } \\
\text { of the programmes). }\end{array}$ \\
\hline $\begin{array}{l}\text { Organisations can self-organise in response to external events, } \\
\text { especially events that are critical to the system's survival. }\end{array}$ & $\begin{array}{l}\text { Some self-organisation took place in the historic transport R\&D programmes studied [3], particularly in } \\
\text { finding alternative local and international funding sources. }\end{array}$ \\
\hline $\begin{array}{l}\text { Complex organisations cannot thrive when there is too much } \\
\text { central control. This certainly does not imply that there should } \\
\text { be no control, but rather that control should be distributed } \\
\text { throughout the system. }\end{array}$ & $\begin{array}{l}\text { The strong central control and administration of the historical RDAC transport R\&D programme [3], with } \\
\text { its consequent negative results, is an example of this in the transport research arena. }\end{array}$ \\
\hline $\begin{array}{l}\text { Complex organisations work best with shallow structures that are } \\
\text { not strictly hierarchical. }\end{array}$ & $\begin{array}{l}\text { In the R\&D process this implies giving more autonomy to research leaders to make decisions about the } \\
\text { direction of the research. }\end{array}$ \\
\hline
\end{tabular}


Table A2: Summary of responses to the survey

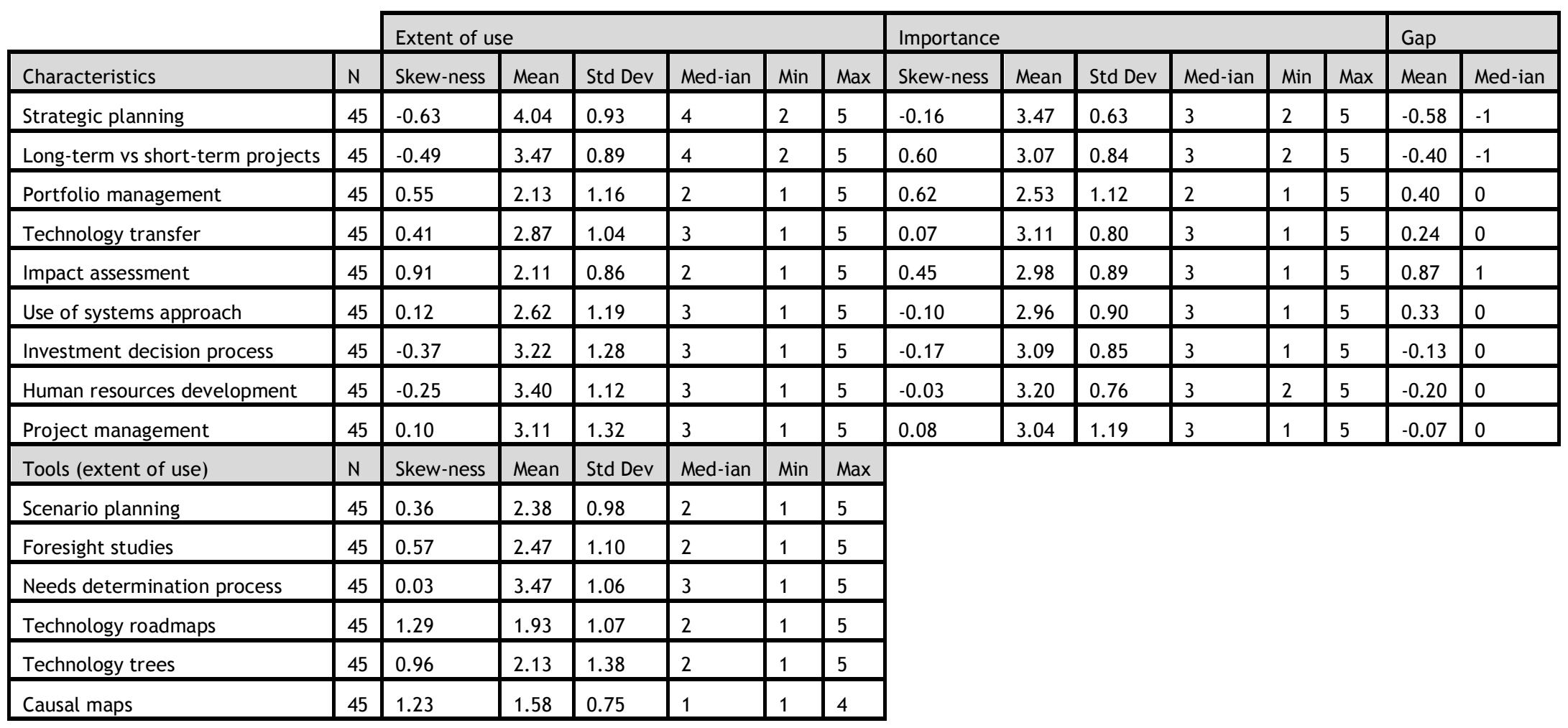

